\title{
DIE VOLKEKUNDIGE AGTERGROND VAN DIE NIGERIESE PROBLEEM
}

\section{A. Inleidend}

Die probleem wat vandag in Nigerië ondervind word, is eie aan feitlik al die moderne Afrikastate. Dit is nl. om die huidige state op 'n aanvaarbare patroon as eenhede te laat funksioneer waar daar vroeër geen eenhede was nie en waar geen uniforme staatspatroon bestaan het nie. Die huidige probleem van nasiebou vind sy oorsprong in die kolonisasietydperk toe grenslyne deur Londen, Parys, Berlyn en Lissabon in Afrika getrek is met ekonomiese voordeel en politieke prestige vir die verdelers as die beslissende faktore. Dit het meegebring dat die politieke grense van die state deur etniese grense heengesny het.

Nigerië is 'n goeie voorbeeld van 'n saamgeflanste ekonomies-staatkundige struktuur waarvan die politieke eenheid en waarde diep te betwyfel is. Die landsgrense van Nigerië het absoluut geen historiese sanksie nie. Die westelike grens tussen Nigerië en Dahomey verdeel bv. die Yorubastamgroep, en die noordelike grens tussen Nigerië en Niger die Hausa. Daarteenoor is die Hausa, Yoruba, Ibo en ander kleiner stamgroepe in een land saamgevoeg. Weens die grootte van Nigerië is die probleem hier besonder ingewikkeld. Die kompleksiteit word saamgetrek in een hooftema, nl. die stryd tussen die drie hoofgebiede: Noord-, Wes- en Oos-Nigerië. Elk van hierdie streke is uitkenbaar en word gedomineer deur 'n etniese groep: in die Ooste die Ibo, in die Weste die Yoruba en die Hausa in die Noorde. Die stryd tussen hierdie groepe het die geskiedenis van Nigerië oorheers. Tussen hulle, in elke gebied, is 'n aantal klein groepies en stamme versprei, elk met 'n eie taal en kultuur.

\section{B. Die land en bevolking}

\section{(a) Bevolkingsamestelling}

Die bevolking bestaan uit verskillende stamgroepe en stamme wat uitkenbaar is aan hulle gewoontes en taal. Die drie groot groepe, nl. die Ibo, Yoruba en Hausa/Fulani, maak $\pm 39 \%$ van die bevolking uit. Daarbenewens is daar sterk 
minderheidsgroepe binne die hoofgebiede. Die totale bevolking is 55 miljoen. Bevolkingsdigtheid toon 'n korrelasie met die klimaatsomstandighede en die nywerheidsontwikkeling. In die Noorde is die bevolkingsdigtheid 60 , in die Weste 151 en in die Ooste 245 persone per vk. myl. Die meerderheid van die mense woon in landboustreke. Die persentasie verstedeliking was die hoogste in die Westelike en die laagste in die Noordelike gebied.

Die samestelling van die bevolking volgens die belangrikste stamme is soos volg:

Noord-Nigerië: Hausa 6 miljoen; Fulani $5 \frac{1}{2}$ miljoen; Kanuri $1 \frac{1}{4}$ miljoen; Tiv 200,000.

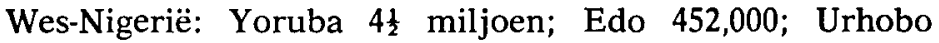
346,000 .

Oos-Nigerië: Ibo 5 miljoen; Ibibio 750,000; Annang 450,000; Ijaw 265,000.

Die persentasie blankes is baie laag. Dit is hoofsaaklik vanweë die strawwe klimaatsomstandighede en die voorkoms van tropiese siektes. Uit die volgende belangrikste tale is daar in Nigerië na skatting 150-250 verskillende dialekte ontwikkel: Hausa, Fulani, Kanuri (Noorde); Yoruba (Weste); Ibo, Ibibio en Efik (Ooste). Engels word as amptelike taal gebruik.

Rassies bestaan daar basiese verskille. Die Hausa/Fulani en die Tiv in die Noorde vertoon sterk Arabierse of Berberkenmerke. Die Yoruba kan as suiwer Neger beskou word, hoewel daar reeds baie Berberbloed in sekere groepe ingedra is. Die Ibo is suiwer verteenwoordigers van die Negerras. Die kleiner groepe vertoon, op enkele uitsonderings na, raskundig dieselfde verspreidingspatroon.

(b) Kultuurhistoriese agtergrond

Die 15e eeu was om drie redes belangrik vir Nigerië. Dit was die tyd van:

Die opkoms van die Hausastate toe die ou Kanem/Bornuryk verswak was.

Die ekspansie van die koninkryke Oyo en Benin.

Die landing van die Portugese.

Daar was verskillende ou ryke in en om die huidige Nigerië gewees voordat die Europeane daar geland het, bv. die Kanem/ 
Bornuryk, verskillende Hausastate, die Nupe, die Jukunkoninkryk, die ryke Oyo en Benin, die Deltastate en die besonder losse Ibogemeenskap.

Die ou Soedanryk het ook 'n belangrike invloed in hierdie gebied uitgeoefen. Tradisioneel was daar definitiewe skakels tussen hierdie ou ryke. Dit het gewissel van diplomatieke betrekkinge tot gedurige oorlogvoering en strooptogte. Daar was dus kultuurkontak en gevolglik kultuurbeïnvloeding. Isolasie het selde voorgekom. Tog het elke kultuur sy eie besondere kwaliteite en eie bepaalde ontwikkelingsgeskiedenis gehad.

\section{(i) Noord-Nigerië}

Geografies en histories behoort die Kanem/Bornuryk, die verskillende Hausastate, sowel as die suidelike buurgroepe, nl. die Nupe- en Jukunkoninkryke, tot die ou sentrale Soedan. Die Nupe- en Jukunkoninkryke het later saam met die Hausa die belangrikste elemente van die magtige Fulaniryk uitgemaak. Kanem was reeds in die 7e eeu belangrik genoeg dat dit aan die Arabiere bekend was. (Die Griek, Herodotus, beskryf trouens al die Arabiere se handelstogte na Wes-Afrika.) Gedurende die $13 \mathrm{e}$ en $14 \mathrm{e}$ eeue was Kanem die onteenseglike heersende staat in die Soedan met die swaartepunt van die ryk ten ooste van die Tsjaadmeer. Die affiliasie met Bornu het in die 13e eeu ontstaan. Dit was 'n affiliasie met die gebied ten weste van die Tsjaadmeer, m.a.w. onder andere die gedeelte wat ons vandag ken as Noord-Nigerië. Op hierdie wyse het die middelpunt van die Kanem/Bornuryk na die weste verskuif. In die 16e eeu was die ryk weens sy handelsbelange eerder aan Egipte en die Ooste verbind as aan die ou Soedan. Dit was veral die geval met Bornu. Hulle was dus onder die Oosterse invloedsfeer ingetrek. Die vestiging van die Islam in Wes-Afrika het dan ook langs hierdie weg plaasgevind. Die Hausagebied is geleidelik deur Bornu oorstroom.

In die 15e eeu het die ryk intern verswak, sodat die Hausaelement ' $n$ beherende aandeel begin kry het. Terselfdertyd is dit deur die Fulani binnegedring en verower. Dit was 'n renaissance-tydperk wat feitlik neergekom het op die organisasie van 'n tweede Kanem/Bornuryk. Teen die 17e eeu was die vormingsproses van verskeie Hausa-stadstate binne die ryk voltooi. Die Hausa was nou die dominante groep binne die 
ryksgebied en het die Hausakultuur en -tradisionele godsdiens weer laat herleef.

Teen die $19 \mathrm{e}$ eeu vind die vervanging van die stadstate deur die Fulaniryk plaas. Dit het deur drie fases heen verloop. Dit het begin as 'n Fulani herlewingsbeweging om die Islam weer te vestig en uit te brei. Tweedens het dit ontwikkel tot 'n nasionale Fulanirevolusie. Derdens was dit 'n populêre omverwerping van die ou Hausa-dinastieë. Die belangrikste gevolg was die vervanging van ' $n$ aantal kompeterende state deur 'n gekonsolideerde ryk. Die Fulaniryk was gebaseer op 'n feodale stelsel wat volgens 'n uitgebreide piramidale gesagstruktuur gefunksioneer het. In hierdie struktuur was die feodale hoofde, die Emirs, die spil waarom die staatsbestuur gedraai het. Die Islam het die etniese verskille oorspan en as 'n bindende krag in die ryk gedien. Ondertrouery tussen die Hausa en Fulani het op so 'n skaal plaasgevind dat slegs 'n paar geïsoleerde nomadiese groepe vandag as suiwere Fulani beskou kan word. Terselfdertyd is daar slegs enkele groepies wat die Fulani weerstaan het en nie aan die Islam onderworpe is nie. Hausa was die aanvaarde taal. Die eenheid wat so verkry is, is die vernaamste rede waarom Noord-Nigerië vandag polities 'n eenheid vorm. Hulle is ook numeries as eenheidsgroep vandag by verre die meerderheid. Hiermee saam het hulle 'n besondere trots ontwikkel, wat veroorsaak dat hulle weinig belang stel in alles wat nie Noord-Nigeries is nie. Dit verklaar o.a. die bestaan van die Northern Peoples Congress as 'n partypolitieke eenheid.

\section{(ii) Wes-Nigerië}

Die Benin- en Oyoryk behoort histories tot die groep state wat in die Guinië-woude ontstaan en ontwikkel het. Tradisioneel vind hulle dus noue aansluiting met die Dahomey- en Ashantiryk van Ghana en omstreke. Daar bestaan min gegewens oor die tydperke voor die 16e eeu. Uit die Oyoryk het die latere magtige Yorubakoninkryk gespruit. Hoe die oorgang plaasgevind het, is onseker. Die tradisionele stamvader was volgens oorlewering Yao-rooba wat uit die Ooste gekom het. Hulle is nie heeltemal van Negeroorsprong nie, maar deur ondertrouery met die verowerde Negerslawe (waarskynlik Oyo) is hulle rassies versuiwer. Hulle is reeds lank genoeg in Yorubaland dat dit as hulle tradisionele tuiste beskou kan 
word. Die Yorubaryk het in vervloë tye gestrek van Accra tot teen die Nigerrivier. Onderlinge clantwis het egter tot die verbrokkeling en inkrimping van die ryk gelei. 'n Voorbeeld hiervan is die goewerneur van Ilorin, wat terselfdertyd ook militêre hoof van die ryk was, wat Ilorin m.b.v. die Fulani tot 'n onafhanklike staat verklaar het. Hierdie staat is spoedig deur die Fulani oorstroom en is vandag 'n voorbeeld van NegerBerber-vermenging. Die Yorubaryk is uiteindelik na die Suide verdryf sodat dit besig was om te disintegreer toe die blankes in Nigerië geland het. Oor die verband tussen Oyo en Benin bestaan daar weinig gegewens. Die Beninryk was die aanleidende oorsaak tot die daarstelling van die Midde-Westestreek in Nigerië.

\section{(iii) Oos-Nigerië}

Die Ibo se stamverband word gegrond op gemeenskaplike taal. Hulle is nie in alle opsigte 'n homogene groep nie. Hulle sosiale organisasie is gebaseer op die familie- of verwantskapsgroep. Die basis van die sosiale eenheid is die patriliniese clan wat ook die hoogste politieke eenheid is. Clanlede woon gewoonlik saam in een dorpie wat as outonome eenheid funksioneer. Dit is een van die kenmerke van die Ibo dat hulle in geslote kompartemente gewoon het, onderling getwis het, mekaar as slawe verkoop het, maar tog 'n mate van eenheid en eendersheid behou het. Die geslote sosiale struktuur is grootliks verhoog deur die natuurlike omstandighede, nl. die digte woude. Die eenheid tussen die dorpies is versterk deur die gebruik dat clanlede gedurig van hulle clan kon wegbreek en hulle by ' $n$ ander kon gaan voeg. Dit het ook voorgekom dat 'n dorpie van 'n bepaalde groep kon wegbreek en by ' $n$ ander groep kon aansluit. Onderlinge skakeling het ook op religieuse gebied plaasgevind. Die sosiale samestelling van die Ibo het later bygedra tot die probleme van Nigerië. Hulle het, toe hulle onder druk verkeer het, baie maklik na die ander gebiede gegaan, maar net so maklik weer teruggekeer toe Biafra onafhanklik verklaar is.

Soos in die ander gebiede het die Ibo 'n geskiedenis van stryd en bloedvergieting wat 'n taamlike verwarrende toestand geskep het toe die Britte met hulle in aanraking gekom het. Daar was geen sprake van 'n sentrale regering of opperheerser, of selfs 'n opperheersende stam nie. 
Dit was min of meer die politieke toestand in Nigerië voor die koloniale tydperk. Geeneen van die bloedige oorloë is tot die einde toe gevoer nie, sodat die posisie nêrens tot helderheid gekristalliseer het nie. Kenmerkend van die gebied was die florerende slawehandel wat onderling gedryf is. Alle krygsgevangenes is as slawe onderwerp of verkoop. Slawestrooptogte was 'n belangrike bedryf. In die Hausaryk is goederehandel feitlik totaal vervang deur slawehandel. Die het hulle verkry van die suidelike buurgroepe asook van die kleiner stamme in die gebied. Die Portugese en Britte het hierdie slawehandel aanvanklik aangemoedig en voortgesit.

\section{(c) Godsdiens}

\section{Noord-Nigerië}

In die Hausa/Fulaniryk was die Islam sedert die $15 \mathrm{e}$ eeu reeds die gevestigde en aanvaarde godsdiens. 'n Godsdienssuiwering het plaasgevind met die Fulanirevolusie. Hiermee het die Islam ook 'n nasionale godsdiens geword.

\section{Oos-en Wes-Nigerië}

Die Yoruba en Ibo het tot en met die Britse okkupasie hoofsaaklik hulle tradisionele animistiese godsdienste bly behou. Die Ibo het bv. 'n pantheon van hoë gode o.l.v. Chuku gehad. Daaronder het hulle 'n lug-, son-, weerlig- en aardgod gehad. Op die derde trap is daar 'n hele reeks ondergeskikte plaaslike gode vir water en landbou, o.a. geeste van geluk, rykdom, krag en die slegte. Voorouergeeste is ook aangeroep. In die laaste plek is daar die belangrike orakels en waarsêers, die sg. Ju-ju. Slawe is dikwels geoffer as boodskappers na die ander wêreld. Die verering van die gode verskil van streek tot streek maar die basiese patroon is dieselfde. Elke dorpie het 'n priester en 'n heilige plek wat die sentrum van hulle kultuslewe is. Senior dorpies, d.w.s. dorpies wat eerste in 'n gebied aangelê is, het 'n senior priester en heilige plek. Gemeenskaplike offers vir die omliggende dorpies word hier gebring. Ook in hulle religieuse lewe het eenheid en differensiasie dus langs mekaar voorgekom.

Christensendelinge het die gebied wat deur die Islam braak laat lê is binnegestroom. Teen 1960 was daar veral in Yorubaland reeds ' $n$ taamlik gevestigde Christendomlike neer- 
slag. By hierdie twee godsdienste het ons die uiteenlopende kulture van die draers daarvan. Die Islam word kultureel gekoppel aan, en staan onder die invloed van, die Oosterse lewenspatroon. Hierdie stempel is tot 'n hoë mate op die Hausa/ Fulani afgedruk. Die Christensendelinge het die Europese lewenspatroon in Suid-Nigerië ingedra. Hierdie twee godsdiensstrome het dit in gemeen dat beide daarop gemik is om andersdenkendes te bekeer. 'n Botsing moes noodwendig volg.

Die komplekse etniese samestelling van Nigerië moet ook tesame met hierdie ingewikkelde godsdienspatroon gesien word. Met die blankes het gekom skrif en 'n gevolglike verbreiding van die horison, o.a. die totaal vreemde (vir die suide) kontantekonomie. Al hierdie kragte het die tradisionele stampatroon verander. Met die vermindering van die etniese op een gebied het terselfdertyd 'n versterking van etniese bande op ander gebiede plaasgevind. Dit het terselfdertyd 'n wye kloof tussen Noord- en Suid-Nigerië laat ontstaan. Dit was alleen maar logies dat met onafhanklikwording die skeure juis sou plaasvind langs die nate van die Britse-vervaardigde lappieskombers.

\section{(d) Nigerië onder Britse bewind}

Europese handelsbetrekkinge met die gebied dateer reeds enkele eeue terug. Die Portugese het reeds in 1472 aan die Nigeriese kus geland, gevolg deur die Britte in 1553. Handelaars is opgevolg deur sendelinge en ontdekkers. D.m.v. verdragsluiting met die toenmalige heersers is die Britse invloed gedurende die $19 \mathrm{e}$ eeu uitgebrei. Aanvanklik was dit private maatskappye wat die gebied beheer het. Gaandeweg is 'n Britse polisiemag, administrateurs en 'n regbank ingestel om die Britse belange te beskerm. Daarmee is 'n nuwe situasie geskep vir nuwe politieke en ekonomiese ontwikkeling. Die handhawing van wet en orde en die kommunikasieweë het eweneens 'n nuwe situasie geskep vir vrye onderlinge verkeer tussen die gebiede.

Die term Nigerië kom in gebruik gedurende die laaste deel van die $19 \mathrm{e}$ eeu. Die gebied het veral bekendheid verwerf as 'n bron van slawe, sodat die Nigeriese kuslyn die twyfelagtige erenaam van die Slawekus verkry het. Van die slawe is gepraat as swart ivoor. (Die benaminge het geskied na aanleiding van die Goud- en Ivoorkus). Die eerste indringing 
in Iboland het dan ook primêr geskied om slawe te werf. $\mathrm{Na}$ skatting is daar gedurende 'n tydperk van 20 jaar \pm 370,000 Ibos na die V.S.A. as slawe verkoop. Nigerië is formeel deur Brittanje oorgeneem uit humanitêre oorwegings. Dit was deel van die ontslawingsbeweging van die tyd. Die land is saamgestel uit die gebiede wat onder maatskappybeheer was t.w. die Colony of Lagos, Oil Rivers Protectorate en die Royal Niger Co.-gebied. In 1914 het Brittanje die verenigde Nigerië as kolonie onder sy beheer gehad met lord Lugard as die goewerneur. Hiermee is 'n nuwe koloniale era ingelui wat onmiddellik 'n nuwe bestuurstelsel vereis het.

Lord Lugard het Noord-Nigerië volgens die tradisionele stelsel van Emirs en Alkali's bestuur. Eg. was feodale hoofde terwyl die Alkali's as regterlike amptenare opgetree het. Belangrik is dat beide die tradisionele bestuursvorm sowel as die regterlike gesag tot op groot hoogte behou is. Die stelsel is slegs gewysig, bv. slawehandel wat afgeskaf is. 'n Beleid van isolasie is t.o.v. die Noorde toegepas. Selfs die Christelike sending is in hierdie streek ontmoedig. Op hierdie wyse het dit in die Noorde aanvanklik taamlik rustig en ordelik verloop. Die bevolking, en veral die leiers, het hulleself nie bedreig gevoel deur die nuwe gesag wat oor hulle gestel is nie. Terselfdertyd is daar 'n gees van separatisme in die Noorde gekweek wat toenemend gegroei het, tot so ' $n$ mate dat regionalisme selfs onder die Britse amptenary posgevat het. Hierdie separatisme het veel bygedra tot die probleme waarmee Nigerië vandag te kampe het.

Die tradisionele lewenspatroon wat so noukeurig deur lord Lugard bewaar is, het weinig ruimte gelaat vir inisiatief onder die burgerlike bevolking. Daarby kom nog dat hulle nie vertroud gemaak is met die Westerse demokratiese stelsel nie, sodat daar in Noord-Nigerië op meer as een terrein 'n groot mate van stagnasie ingetree het. Hierdie agterlikheid ten spyt, het die Hausa - van nature hooghartig en trots op hulle verlede - neergesien op die suidelike groepe wat hulle as barbare beskou het.

Met wanorde in die verbrokkelende Yorubaryk het Brittanje hom genoodsaak gevoel om 'n stelsel van direkte beheer oor hierdie streek in te stel. Selfontwikkeling was aanvanklik net nie moontlik nie, aangesien die clanhoofde gedurig in stryd was met mekaar. Op hierdie wyse het veel van die tradisionele verlore gegaan. Wes-Nigerië is deur Britse amptenare 
en sendelinge oorstroom, sodat verwestering en ontstamming al gou hier plaasgevind het. (Hierdie twee prosesse het hier gelyktydig plaasgevind). 'n Nuwe elite, nl. die Africans, is hier gebore. Hulle was trots op hulle status as Christene en "geleerdes". Die vele sendingskole het hierin 'n belangrike bydrae gelewer. Die Yoruba het hulleself al gou gesien as die keur van nuwe Nigerië wat met reg kon neersien op die Moslems en op die heidense en ongeletterde Ooste.

Lord Lugard het tevergeefs gepoog om aansluiting te vind by die regeringstelsel van Iboland. Die Britte het egter weinig begryp van die kompartementele clanstruktuur van die Ibo. Ook hier was hulle dus genoodsaak om 'n stelsel van direkte beheer in te stel om sodoende eenheid en ,orde" in Oos-Nigerië te bewerkstellig. ' $n$ Belangrike bydrae is deur Brittanje gelewer deur 'n paaienetwerk deur die oerwoud te kap. Hierdeur is verbinding en onderlinge verkeer tussen die Ibo-gemeenskappe verseker. Dit was ' $n$ belangrike element in die kweek van 'n nuwe Ibo-nasionalisme. Britse intervensie het ook 'n ander kenmerk van die Ibo na die oppervlak gebring, nl. hulle vitaliteit. Met die vestiging van sendingskole het die persentasie geletterdheid onder die Ibo vinnig toegeneem, sodat 'n arbeidsvraagstuk al gou daar geskep is. Weens hulle wye sosiale samestelling het die Ibo self hierdie probleem opgelos deur na die Yoruba- en Hausagebiede oor te loop.

In hierdie gebiede is hulle op twee maniere ontvang. Die Yoruba, wat hulleself as die uitverkore Nigeriërs gesien het, was onmiddellik jaloers op en vyandig teenoor die reeds gehate Ibos. Die vloedgolf Ibos was egter oorweldigend. Die trotse Hausa het neergesien op die „barbaarse” Ibo, maar hulle laat begaan, aangesien hulle bereid was om te werk. (Die Hausa was gewoond aan slawe). So het die Ibos ingedring in feitlik elke sektor van die ekonomiese lewe en, veral in die Noorde, feitlik beheer daaroor verkry. Op sosiale en politieke gebied het die Ibos egter geen regte of voorregte bekom nie. In die Noorde bv. was die Moslemwette volgens die Malikileer nog van toepassing. Hiervolgens is slegs ses oortredings omskryf en bepaal. Die res word aan die diskresie van die hof oorgelaat. Hiervolgens mag die verwante, bv. van 'n vermoorde, bloedgeld of die lewe van die moordenaar eis. 'n Animis, soos die Ibo, mag egter nooit die lewe van 'n Moslemmoordenaar eis nie en slegs $1 / 15$ van die gewone bloedgeld. Die status van die Christene lê tussen die Moslem en die animiste. Ten 
einde orde te handhaaf is die reg op een basis geplaas. Dit het die ywer van die Emirs opgewek en die Ibos gehaat gemaak.

Dit was die rigting waarin Nigerië beweeg het onder die Britse bewind. Dit was 'n tydperk ( \pm 50 jaar) van betreklike rus en orde. Dit was 'n tydperk van inname waartydens die Nigeriërs gedrink het uit die beskawingsbeker wat Brittanje aangebied het sonder om altyd in staat te wees om dit te kan verteer. Met die hand van Brittanje stewig op die pols, kon 'n ernstige krankheid egter betyds afgeweer word. Nigerië het onafhanklikheid in 1960 verkry en op 1 Oktober 1963 'n Federale Republiek binne die statebond geword.

\section{Probleemstelling}

Die kernvraagstuk van die probleem is of nasiebou soos dit in Nigerië aangepak is, moontlik is of nie. Met hierdie vraag betree ons dadelik die terrein van die teoretiese Volkekunde. Vir eers moet onderskeid gemaak word tussen nasie en volk. Nasiebou is moontlik deur verskillende bevolkingselemente in een politieke staat saam te voeg. Volkwording is 'n groeiproses, nl. tot 'n algeheel geïntegreerde eenheid wat na buite duidelik sigbaar is in ' $n$ nasionale eenheidsgrees en eenheidstrewe. Nasiebou kan oorgaan tot volksgroei. Die vraagstuk van nasiebou uit 'n samestelling van etnies en kultureel verskillende elemente is eie aan die meeste Afrikastate. In Nigerië is daar $\pm 150-250$ aparte taalgroepe wat verspreid is oor die hele landsgebied, met die dominante groepe in elke streek. Hierby kom nog die skerp godsdiensverskille. Hierdie probleme is die wesentlike erfenis van die Europese sug na rykdom.

Om die probleem verder te begryp, moet onthou word dat ons te doen het met primitiewe stamkulture in die Suidelike state wat die oog gerig hou op Europa, en met 'n Oostersbeïnvloede en -gerigte Noorde. In hierdie stamkulture sien ' $n$ individu homself altyd as ' $n$ deel van 'n sosiale sisteem wat op 'n bepaalde, vir hom bekende, manier funksioneer. Hierdie sosiale gemeenskap domineer sy hele doen en denke en dit dwing dus noodwendig uniformiteit af. Dit sou onrealisties wees om te verwag dat hy hierdie tradisie sonder meer moet verwerp. Dat daar reeds 'n mate van 'n losmakingsproses plaasgevind het, lei geen twyfel nie. Lord Lugard het die bevolking van Nigerië reeds geklassifiseer in primitiewe stamme, ontwikkelde gemeenskappe en Europianiseerde Afri- 
kane. Dit is die Africans, wat leer lees en skryf het, wat vandag nog aan die roer van sake staan. Uit hulle mond verneem ons die - vir Afrika - vreemde klanke van neo-kolonialisme, nasionalisme, sosialisme, demokrasie, rassisme. Hierdie groep, wat nog dronk en oorweldig is van die aansien wat hulle so skielik in die wêreld geniet, is gewoonlik die ekstremiste wat deur mag en geweld hulle gesag wil afdwing en ten alle koste hulle posisie wil behou. Hulle slagspreuk is, ironies genoeg, weg met alles wat blank is! Om hierdie redes word die verstand dikwels te maklik deur die emosie oorheers.

In skerp teenstelling met hierdie groep vind ons die bevolking, die onderlaag, waarop die prestige van die leiers rus. Die leiers kan noodwendig nie van die volk losgemaak word nie en juis dit veroorsaak ' $n$ onewewigtigheid wat in die huidige bedeling die kern van hulle probleme vorm, aangesien dit direk terug geprojekteer word na die grondoorsaak die etniese verskille. In Nigerië kom hierdie situasie veral in vier hoofmomente na die oppervlak, naamlik:

Federasievorming;

die stigting van politieke partye;

die rol van die leiersfigure;

die rol van die opposisie.

\section{(a) Federasievorming}

Met onafhanklikwording het Nigerië in 'n onewewigtigheidstoestand verkeer. Dit dateer reeds terug na die prekoloniale tydperk waartydens die fondamente van die drie streke gelê is. Dit is opgevolg en versterk deur die Britse beleid van isolasie van die Noorde. Uit die konferensies oor die onafhanklikheid het duidelik geblyk die onwilligheid van die noordelike Emirs om te federeer en hulle gretigheid om af te skei. Sporadiese gevegte gedurende hierdie tyd tussen Hausaen Ibogroepe het die spanning verhoog. Die Noorde het besef dat hulle nie die Europese leefwyse baasgeraak het nie. Hulle was nog nie gereed vir onafhanklikheid nie en hulle het hulleself steeds op 'n afstand gehou van die Europianiseerde Suide. Dit is die belangrikste rede waarom die Noorde gekant was teen 'n bepaalde datum vir onafhanklikheid. Hulle wou die saak op die lange baan skuif.

Die gevolg van hierdie spanning was dat die konstitusie by die streeksbeheptheid aangepas is. Reeds die feit dat Ni- 
gerië ' $n$ federasie is, is ' $n$ gevolg van onoorbrugbare verskille. Konstitusioneel is bepaal dat ' $n$ federasie met drie groot streke tot stand sou kom. Onmiddellik het die minderheidsgroepe hierteen in verset gekom. Dit het die vraagstuk laat ontstaan van die aantal streke wat ingestel moet word. Hierdie vraagstuk het deur die hele stryd heen geloop en het uiteindelik een van die wesensoorsake geword van die breuk tussen die Federasie en Biafra. Al hierdie politiekery was slegs 'n spieëlbeeld van die wantroue tussen die groot groepe en die vrees vir oorrompeling van die kleiner stamme. Dit was juis die kleiner stamme wat 'n politieke magsfaktor geword het wat bepalend sou wees vir die verloop van die stryd.

Ook op 'n ander wyse is die konstitusie aangepas by hierdie inter-etniese stryd. Voorsiening word konstitusioneel gemaak vir sesessie. Dit mag plaasvind indien twee derdes van die drie bestaande streke en $60 \%$ van die kiesers in die betrokke gebied afskeiding verlang. Gemeet aan die Westerse demokratiese standaarde, is dit 'n goed verskanste klousule; in die lig van Afrika se eenpartypolitiek sonder verkiesings, 'n blote formaliteit.

(b) Vorming van politieke partye

Die stelling dat elke streek uitkenbaar is en gedomineer word deur 'n etniese groep, is ook toepasbaar op die politieke partye.

(i) Die noorde

Die etniese gerigtheid was hier van die begin af in die politiek teenwoordig. Die Islam het 'n politieke krag geword wat met die Northern Peoples Congress (N.P.C.) geassosieer is. (Daarteenoor het die Christendom geen politieke invloed gehad nie maar eerder in 'n sosiaal opvoedkundige rigting beweeg.) Die N.P.C. is 'n geslote politieke party, slegs toeganklik vir diegene wat in die Noorde gebore is. Dit het 'n staat binne 'n staat geskep wat op etnies-religieuse gronde gevestig is. Dit verklaar waarom die Noorde so gekant is teen enige vorm van onderverdeling. Daar bestaan ook ' $n$ interessante kombinasie in die partystruktuur. Die eerste president van die party, sir Ahmadu Bello, was 'n Fulani-aristokraat en aanspraakmaker op die hoogste Islamse posisie in NoordNigerië, nl. die Sultan van Sokota. Die onder-president was die African, sir Abubakar Balewa (Islam). Sir Ahmadu het 
ten gunste van sir Abubakar teruggestaan tot na die eerste verkiesing, en toe weer kragtens sy tradisionele status aanspraak gemaak op die algehele leierskap. Op hierdie wyse het sir Ahmadu die brein en sir Abubakar die mondstuk van die party geword. Dit was nie vreemd dat dit juis hulle was wat tydens die eerste staatsgreep deur die Ibos vermoor is nie.

\section{(ii) Die weste en ooste}

Onder die Yoruba is die Action Group (A.G.) o.l.v. die reaksionis, dr. Azikiwe, die heersende party. Hierdie party het na die eerste verkiesing die amptelike opposisieparty geword. Onder die Ibo was die National Council of Nigeria and the Cameroons (N.C.N.C.) die politieke uitlaatklep. Aanvanklik was daar eensgesindheid tussen die leiers van die twee partye, nl. dr. Azikiwe en mnr. Awolowo. Albei was Africans wat 'n demokratiese staat in Nigerië wou vestig. Albei het egter gestreef na die leierskap, sodat dit op 'n botsing uitgeloop het. Die meningsverskil was reeds in 1941 sigbaar in 'n jeugbeweging, die National Youth Movement (N.Y.M.). Bestuurslede is hier op 'n stambasis verkies, sodat dit uiteindelik tot 'n verdeling van die beweging gelei het. Hierdie neiging het deurgewerk na die twee partye, die A.G. en N.C.N.C., wat as stampartye voortbestaan het.

Die skeuring tussen hierdie partye is terug te voer na die jaloesie van die Yoruba op die ekonomiese vooruitgang wat die Ibos gemaak het. Dit het die partydigheid van die verkiesings in die N.Y.M. geïnspireer. Die breuk wat hierdeur ontstaan het, het 'n kloof geword tussen die twee stamme, wat 'n belangrike faktor geword het in die partypolitieke wese van Nigerië.

Die eerste reaksie het gekom kort voor die federasievorming toe $\mathrm{dr}$. Azikiwe, wat etniese selfontwikkeling vir minderheidsgroepe voorgestaan het, die federasie met drie streke aanvaar het. Die minderheidsgroepe in die Weste het hieroor in oproer gekom en gegryp na aanknopingspunte om selfbehoud. Die sterkste van die minderheidsgroepe, die Edo, het as die nasate van die ou Beninkoninkryk tevoorskyn getree. Uit hierdie nuwe eenheidsgroep is later 'n vierde streek nl. die Midde-weste gebore. Dit het die party van dr. Azikiwe aansienlik verswak. 


\section{(iii) Partypolitiek}

Met die verkiesing in 1957, kort voor onafhanklikheid, is die etniese stryd wat deur Britse intervensie in 1914 beëindig is, voortgesit. Die 50 jaar onder Britse bestaan was niks anders nie as 'n gedwonge wapenstilstand, wat die verskillende partye die geleentheid gegee het om hulle magte te konsolideer en te hergroepeer. Uit die ryke beloftes wat die drie groot leiers gemaak het, was aaar weinig te kies. Al drie het, veral vir die minderheidsgroepe, volle waarborg van voortbestaan voorgehou. Dit was duidelik dat die stryd gebaseer was om die guns van die minderheidsgroepe te wen. Die uitkoms van die verkiesing was die eerste aanduiding van die koers waarin Nigerië sou beweeg. Die N.P.C. van die Noorde het die eleksie met 148 setels gewen; 134 setels was in die Noorde geleë en 14 was onafhanklikes van minderheidsgroepe wat na die verkiesing by die sterkste party aangesluit het. In die verkiesing was die A.G. van die Weste die enigste party wat meer setels buite as binne die tradisionele stamtuiste verower het. Hiervoor was daar hoofsaaklik twee redes:

Die verswakking van die party in die Weste a.g.v. Edoseparatisme.

Gedurende die verkiesingsveldtog is onafhanklikheid aan alle minderheidsgroepe beloof. Dit was juis in die gebiede van die minderheidsgroepe waar die A.G. hulle setels verower het.

Dit is duidelik dat die dominante faktor in die 1959-verkiesing bo alle twyfel etnies-religieuse belange was. Uit die eleksie kon onmoontlik bepaal word wat die kieserskorps verwag het van die regering t.o.v. binnelandse en buitelandse beleid. Die regering wat verkies is, was allermins nasionaal. Die N.P.C. van die Noorde net die verkiesing gewen bloot omdat daar 'n getalle-oorwig in die Noorde was. Sprekend in hierdie situasie is die eksklusiewe lidmaatskap aan die N.P.C., en treffend die feit dat die tradisionele hoof van die Noorde homself na die verkiesing weer op die voorgrond gestel het as die natuurlike en aangewese leier van die nuwe Nigerië.

(c) Die rol van die leiersfiguur

(i) Die persoon

Tradisioneel is die kaptein of hoofman van 'n stam die 
middelpunt van die stam en die embleem van die stameenheid en voortbestaan. In hoeverre die bevolking die huidige politieke leiers sien as soortgelyk aan die ou hoofmanne, is moeilik om vas te stel aangesien juis die leiers in die rigting van ontstamming beweeg. Daar is tog enkele aspekte in hulle huidige struktuur wat daarop dui dat die politici omvou word met die mantel van gesag wat op die skouers van hulle tradisionele voorgangers gerus het. Die Emirs van Hausaland was soos die Obas van Yorubaland en Benin erflike hoofde beklee met despotiese magte. In Iboland het die clanhoofde 'n ietwat laer status gehad, hoewel nie binne die eie kring nie. Tradisioneel was titels in Iboland 'n belangrike onderdeel van hulle samelewing. Status en titels was sinoniem. 'n Lid met 'n lae status kon 'n titel „koop”. Dit was egter onderhewig aan die goedkeuring van diegene wat reeds met gesag beklee was. Verder moes 'n persoon ' $n$ bepaalde inlywingseremonie ondergaan waarna hy dan tot 'n nuwe en hoër statusgroep of Ozo behoort. Die wese van die inlywingseremonie is 'n seremoniële dood wat die persoon sterf en dan as ' $t$ ware in die nuwe Ozo gebore word. Die gesag wat so 'n persoon dan het, is direk afkomstig van die voorouers. Die persone wat dus aan die hoë gesagskaste behoort het, het die rol vervul wat in ander stamme deur stamhoofde vervul is.

In die huidige Noord-Nigerië word die opvatting gehuldig dat as 'n politikus eers eenmaal verkies is, behou hy sy posisie lewenslank. Om hom te opponeer is net so immoreel as om 'n erflike stamhoof se gesag in twyfel te trek. Vir die Hausa is dit logies en aanvaarbaar, maar dit gaan nie op vir die Ibo nie, aangesien erflikheid vir hom nie bepalend is nie. In al die konstitusionele krisisse in Nigerië het die hoofmanne 'n leidende aandeel gehad. Dit skyn dus asof die stamsentiment wat sentreer rondom die hoofman nog te sterk is, dat gekose leiers heeltemal inslag vind. (Dit geld trouens van die hele Afrika). Daar heers verwarring oor die gesag wat die persoon van die leier omstraal. Terselfdertyd is daar nog geen ander element waarom 'n nasionale sentiment geweef kan word nie. Die leier se posisie is ook religieus gegrond aangesien sy gesag direk van goddelike oorsprong is. Die piramidale gesagstruktuur loop uit tot by die Opperwese aan die spits. In hierdie patroon het die individu geen seggenskap nie en kan hy dus ook nie die wese van 'n verkiesing peil nie. Die politieke sfeer word dus in hierdie eenlynige bonatuurlike 
orde geplaas met die opperhoof of partyleier as die skakel tussen die gode en die mense. Die sg. verenigde partye, wat in wese eenparty-diktature is, is die logiese uitkoms van so 'n beredenering.

\section{(ii) Beleid}

Die Westminsterstelsel van partypolitiek wat om die partyleier draai, skep verwarring in Afrika. Waar die Britse partyleier jaarliks verslag moet doen van sy bedrywighede, word die Afrikaleier gesien as 'n outokraat wat nie weerspreek mag word nie. Balewa se eerste stap was om die belange van die regerende party (dus die noordelike streek) pertinent op die voorgrond te plaas. Daarteenoor is daar openlik gediskrimineer teen andersdenkendes. In hierdie proses het Balewa reeds die weg voorberei vir sy eie ondergang.

Omdat hy nie ' $n$ meerderheid behaal het nie, moes 'n koalisieregering gevorm word. Dit is gevorm tussen die Noorde en Ooste. Hierdie koalisie lyk onverklaarbaar omdat die konserwatiewe en progressiewe elemente van Nigerië daarin verteenwoordig is. Balewa het dit egter primêr gemik teen Azikiwe se party wat, soos hy dit gesien het, met die minderheidsgroepe geheul het. Die Ooste is onskadelik gestel deur die Ibos stelselmatig uit sleutelbetrekkings uit te werk en te vervang met (onbekwame) Noordelikes. Hierdie regionalisme, tesame met die diskriminerende optrede van die regerende party was Nigerië se grootste bedreiging.

Die binnelandse beleid van sir Abubakar Balewa kan die beste opgesom word in sy eie woorde. Toe hy aangewys is as Federale premier, het hy verklaar dat wanneer Brittanje padgee..., the Northern people would continue their interrupted conquest to the sea" (F. A. O. Schwarz, Nigeria ...). Die verkiesingsoorwinning is vertolk in militêre taal. Vir hulle beteken dit ekonomiese voorspoed aan al die ondersteuners. Dit geskied op die beginsel van buitverdeling waarvolgens elkeen sy regmatige deel moet kry. Vandaar dan ook die weelderige lewe van die ministers. 'n Ander uitlating van die premier beklemtoon dieselfde gesindheid. Sommige van die kleiner groepe wat nie deur die Fulaniryk geabsorbeer is voor die Britse intervensie nie, het hy bestempel as die van sy grootvader geërfde rykdomme wat aan hom behoort. Teenoor hierdie heerssug van die politieke leier vind ons die 
natuurlike reaksie - afskeiding. Voorbeelde daarvan is die Bornu-jeugbeweging, die Benin-oplewing en die afskeiding van Biafra.

\section{(iii) Militêre leiers}

Tradisioneel was die stamhoof en militêre hoof een persoon. Waar daar skeiding van die ampte was, was die militêre leier 'n hoogaangeskrewe persoonlikheid. Staatsgrepe en afskeiding deur militêre geweld is geen vreemde verskynsel in Afrika nie. Die Ilorin-provinsie van die Oyoryk is 'n goeie voorbeeld hiervan. Die hedendaagse militêre leiers se taak word vergemaklik deurdat die leër gewoonlik die enigste georganiseerde magseenheid is.

Die huidige stryd tussen die twee militêre leiers is nie heeltemal te isoleer van die tradisie nie. Ojukwu het sy posisie verwerf op grond van sy rykdom (sy vader was 'n oliemagnaat). $\mathrm{Hy}$ is in die moderne ekonomiesgerigte Iboland met veel status beklee. Hy het die leier geword van die nuwe Ibogemeenskap. Hulle is trots en glad nie beskeie oor hulle goeie hoedanighede nie met 'n sterk nasionale (Ibo) lojaliteit. Hulle verag almal wat nie teen hulle opweeg nie. Hoever hierdie veragting strek, is sprekend uit Ojukwu se opdrag aan sy soldate dat hulle 10 Noordelikes se hoofde moet saambring vir elke Ibo wat vermoor is. Dit toon ook die waarde wat 'n menselewe het - wesentlik nie anders as in die tyd van die slawehandel nie.

Teenoor Ojukwu staan Gowon: bekwaam, 'n skrander leerling en 'n uitmuntende soldaat. Hy kom van een van die kleiner stamme van die Noorde en staan dus (nie heeltemal willoos nie) onder die hiel van die grootste magsfaktor in die Noorde, die Emirs. Hoewel hy 'n Christen is, het hy in sy leërs Moslemsoldate - seuns van Islam - wat volgens die tradisie ywerig besig is om die heilige oorlog, die Jehad, teen die materialistiese barbare van die Suide te voer. Daar woed dus geen burgeroorlog in Nigerië nie; dit is inderdaad oorlog - 'n stam- en geloofstryd.

\section{(d) Die rol van die opposisie}

Die A.G. van die Weste was die eerste amptelike opposisieparty. Al gou het politieke opposisie ontaard in persoonlike aantygings en foutvindery. Daar is drie temas gekies: 
Die regering (N.P.C.) is bestempel as Brittanje se "Goodboy".

Die ekonomie het in die hande van die blankes gebly.

Korrupsie en immoraliteit was aan die orde van die dag.

In 'n jong Afrikastaat was die eerste 'n fatale betiteling. Die optrede, en die reaksie wat daarop gevolg het, moet teen die agtergrond van twee reeds genoemde aspekte gesien word, naamlik:

Die tradisionele veragting van die Hausa vir die Yoruba.

Die onaantasbaarheid van 'n leier.

In die lang en ingewikkelde skaakspelery tussen die A.G. van die Weste en die Federale Koalisieregering, is die Weste uiteindelik verdeel en die A.G. verbrokkel. 'n Noodtoestand is in die Weste afgekondig en die gebied onder beheer van 'n Federale (Hausa) goewerneur geplaas.

Met die verwydering van die amptelike opposisie, was Nigerië prakties 'n eenpartystaat. Dit het egter 'n kettingreaksie aan die gang gesit wat gelei het tot die skeuring tussen die Noorde en die Ooste. Die stryd wat hier begin is, duur nog steeds voort. Hiermee is op politieke gebied deurgevoer wat sedert die 1959-verkiesing op ander terreine plaasvind, nI. die bevoordeling van partylede ten koste van die opponerendes. Met die 1964-verkiesing vind ons 'n herhaling van die 1959-gebeure, behalwe dat die stryd toe gevoer is tussen die Noorde en die Ooste. Die voorafgaande sensus het reeds spanning veroorsaak toe hulle mekaar oor en weer beskuldig het van oorskatting. Dit was slegs die logiese benadering van 'n verkiesingstryd wat op etniese groepering gebaseer is. In so 'n geval is getalle van deurslaggewende belang. 'n Nuwe koalisie is nou gevorm, nl. tussen die N.P.C. en die nuwe Yorubaparty. So is die enigste ander sterk party, die N.C.N.C., tot opposisieparty gemaak.

Die gewilligheid van opposisiepartye, asook kleiner groepe, om na die regerende party oor te stap, moet teen die agtergrond van die bogenoemde gebeure gesien word. Binne die regerende party is daar geleentheid vir selfhandhawing. Opposisie buite die regering is kragteloos, aangesien 'n besluit van die regering tog nie op so 'n wyse herroep kan word nie. Verder is 'n opposisie 'n ondermyning van die dissipline, aangesien ' $n$ besluit wat geneem is, uitgevoer moet word. Balewa 
het met sy bewindsaanvaarding dan ook alle opposisiepartye uitgenooi om by hom aan te sluit.

Die eventuele toestand na die 1964-verkiesing was dus 'n algemene tevredenheid onder die Hausa omdat hulle alles regeer het; frustrasie onder die Yoruba vanweë die popperegering in die streek; frustrasie onder die lbo omdat hulle van alle ekonomiese regte en voorregte ontdaan is. Die gevolg was 'n Ibo-staatsgreep waartydens sir Abubakar Balewa en sir Ahmadu Bello en verskeie Noordelike leëroffisiere vermoor is. Dit het onmiddellik onder die noordelike Emirs 'n nuwe vrees laat ontstaan, $\mathrm{nl}$. 'n vrees vir Ibo-oorheersing, sodat ' $n$ tweede staatsgreep gevolg het. Hiermee is die mag weer terug in die hande van die Noordelikes. Duisende Ibos is vermoor, 'n Ibo-migrasie na die Ooste het gevolg en Biafra is tot onafhanklike republiek verklaar. Hierin sien ons 'n teruggrype in die verlede. Biafra was nl. die naam van die gebied rondom die $16 \mathrm{e}$ eeu.

\section{Samevatting}

In 'n vorige voordrag het prof. J. H. Coetzee oor die problematiek van volkswording in Afrika op verskeie faktore gewys wat nodig is vir die proses van volkswording. Daar is o.m. genoem die historiese faktor; die kulturele agtergrond; die intellektueel-psigologiese probleem van die verbreding van die denke; 'n gemeenskaplike vaderland; getalsverhoudinge; gemeenskaplike taal; religie; rassiese eenheid. Wanneer hierdie faktore op Nigerië toegepas word, vind ons dat dit hoofsaaklik skeidend werk.

Uit die voorgeskiedenis is dit reeds duidelik dat ons met tradisioneel botsende volke te doen het. Meeste van die volke in Nigerië was in een of ander staat van oorlog of rebellie ten tye van die blanke besetting van die gebied. Met die Britse tussenkoms is vrede afgedwing en 'n gebied geskep waarin die basiese en enigste eenheidsfaktor die gemeenskaplikheid van die Britse teenwoordigheid was. Die voormalige opposisieleier, Awolowo, het oor die eenheid van Nigerië gesê: „Nigerië is geen volk (Nation) nie. Dit is bloot 'n geografiese uitdrukking. Die woord Nigeries (Nigerian) het slegs die betekenis om dié wat in Nigerië woon, te onderskei van die wat buite Nigerië woon".

Oor die probleem van die kulturele agtergrond, nl. of 
volke kultureel aanpasbaar is of nie, bestaan daar ook skerp verskille. Die Hausa wat steun op die ou kultureel ontwikkelde Kanemryk, was veetelers, landbouers en handelaars. Daarby was hulle 'n skrifhebbende volk. Daarteenoor het die Ibo tradisioneel ' $n$ bestaansekonomiese leefwyse gehad met landbou (weens die klimaatsomstandighede) as die vernaamste bedryf. Bedryfsdifferensiasie was beperk tot die geslagte.

Nou verbonde aan die vorige twee is die probleem van die verbreding van denke. Daar bestaan weinig lojaliteit teenoor Nigerië as land. Daarteenoor staan die stamlojaliteit steeds voorop. Dit is trouens die wese van die hele stryd. Die probleem word nog groter aangesien fisiese vermenging tot 'n minimum beperk is. Die noodsaaklike proses van akkulturasie is en word hierdeur vertraag. Elke groep het in hulle voorouerlike gebied gebly en het daarin psigologies vasgegroei. Die Ibo het hierdie reël tydelik verbreek en juis dit het die oorsaak van veel stryd geword. Die Ibo het tans, interessant genoeg, die beste voorbeeld geword van die sterk stamnasionalisme wat nog bestaan. Hierdie vraagstuk was o.a. bepalend vir die daarstelling van die federasie.

Oor die vraagstuk van die gemeenskaplike vaderland, staan Nigerië voor die probleem dat elke groep daarop aanspraak maak kragtens hulle tradisie, met gevolglike botsende belange. Daar heers eerder ' $n$ houding van gebiedsoorheersing as van gebiedsverdeling. Dit moet ook nog verbind word aan die opvatting van die voorvaderlike vaderland.

Getalsverhoudinge het ' $n$ oorweldigende rol gespeel in die partypolitiek. Eers was dit die minderheidsgroepe, en daarna die groot groepe wat spanning veroorsaak het.

Die taalprobleem is in Nigerië op praktiese wyse oorbrug. Elke taalgroep het die reg behou om sy eie taal te handhaaf. Engels, die gemeenskaplike taal, word as amptelike taal gebruik. Die vraag is egter of Engels al so diep gewortel is dat dit as gemeenskaplike taal sal bly voortbestaan. Met die emigrasie van die Britte mag die invloed van hulle taal ook afneem.

Tesame met die etniese verskille lê die godsdiensverskille aan die wortels van die land se vraagstukke. Die tradisionele animistiese godsdienste kan as "verdraagsame" godsdienste beskou word. Daarteenoor staan die militante Islam met 'n houding van "bekeer jou of sterf" - in die Noorde reeds die gevestigde en oorheersende godsdiensvorm. Minder gevestig 
en nie militant nie, maar tog onverdraagsaam, is die Christendom. Sending is die opdrag. Hierdie godsdienselemente kan en het alleen maar skeurend gewerk.

Rassies is die land in twee verdeelbaar. In die Noorde tref ons die Berberelement aan en in die Suide die suiwer Negers. In samehang met ander faktore mag dit ook 'n skeidende element word.

\section{Slotopmerkings}

Met al hierdie skeidende kragte aan die werk, ontstaan die vraag: wat hou Nigerië aanmekaar? Eerstens moet gelet word op die natuurlike gesteldheid van die land. Brittanje het die ekonomie hierby aangepas, sodat komplementêre bedrywe volgens 'n markekonomiese stelsel in die verskillende gebiede ontwikkel is. Dit het 'n interafhanklikheid tussen die streke geskep wat afskeiding ekonomies feitlik onmoontlik maak.

Die ander en waarskynlik die belangrikste rede moet gesoek word in die geestelike toestand waarin die leiers van Nigerië - soos trouens die van die hele Afrika - verkeer. Kind van die verwesterde Afrika-gemeenskap, African, gedurig onder die internasionale soeklig, probeer hulle aan die eise wat die wêreld aan hulle stel voldoen. Hulle het die uitdaging manmoedig aanvaar.

Die mening is lank gehandhaaf dat Afrika se geskiedenis begin het met die tydperk van kolonialisme. Die hoofrede hiervan is die idee dat die leegheid van die Afrika-voorgeskiedenis (wat eintlik 'n gebrek aan kennis aan die kant van die Westerlinge is) gekoppel word aan die leegheid of onvermoë van die Negroïde brein. Omdat die aanval geloods word op die rassiese onvermoë, word dit vir die Africans 'n faktor van nasionale belang. Vandaar dan ook die klem op die rassiese eenheidsband. Daar is dus 'n gemeenskaplike reaksie teen kolonialisme wat Afrikane verenig. Dit dien as katalisator vir nasionalisme.

Hierdie nasionalisme wat gegrond word op die rassiese eenheid, sny egter na twee kante toe. Dit skep eenheid, maar om dit te bewys word daar in die verlede, met al die verhale van etniese skeiding en broedertwis, teruggegryp. Dit is die dilemma waarvoor o.a. Gowon staan. Dit skyn asof hy op die oomblik nie in staat is om die probleem op te los nie. Of 
'n oplossing moontlik is? Daaroor word nie gespekuleer nie. Dit is alleen maar duidelik dat sy taak reusagtig groot is miskien te groot vir een man of selfs vir een geslag.

23 Augustus 1967.

H. van der Wateren.

AANHANGSEL

\section{GEBEURE VAN HISTORIESE BELANG SEDERT 1959}

1959: Eerste algemene verkiesing met die oog op die samestelling van 'n regering vir die toekomstige onafhanklike Nigerië. Alhaji sir Abubakar Tafawa Balewa se party wen die verkiesing.

1960: Onafhanklikheid word deur Brittanje toegeken.

1962: Verbrokkeling van die Aksiegroep en die instelling van 'n Noodregering in Wes-Nigerië.

1963: Nigerië word 'n Federale Republiek binne die Statebond.

1964: Sensus en tweede algemene verkiesing.

Jan. 1966: Junior leëroffisiere uit die Ibostam pas 'n staatsgreep o.l.v. maj.-genl. Aguiyi-Ironsi toe. Nigerië verkeer van 20 Jan. 1966 af onder ' $n$ militêre bewind. Balewa en sir Ahmadu Bello word vermoor.

Mei 1966: Ironsi kondig 'n unitêre staat met verdwyning van gebieds. regerings aan.

Julie 1966: 'n Tweede militêre staatsgreep o.l.v. lt.-kol. Jakubu Gowon. Ironsi word vermoor.

Mei 1967: Gowon verdeel Nigerië in 12 streke.

Mei 1967: Lt.-kol. Odumegu Ojukwu verklaar Oos-Nigerië tot die onafhanklike Republiek van Biafra.

Julie 1967: Gevegte tussen die troepe van Biafra en die Federale regering breek uit.

\section{LITERATUURLYS}

Burns, Sir A.: History of Nigeria. Allen \& Unwin, 1951.

Central Office of Information: Nigeria the Making of a Nation. London 1960.

Coetzee, J. H.: Die problematiek van volkswording in Afrika. AfrikaSeminaar, P.U. vir C.H.O., 1967.

Davies, Chief H. O.: Nigeria the prospects for democracy. Weidenfeld and Nicolson, 1961.

Elias, T. O.: Nigerian Land Law and Custom. Routledge and Paul, 1953.

Hodgkin, T.: Nigerian Perspectives. O.U.P., 1960.

Meek, C. K.: Law and Authority in a Nigerian Tribe. O.U.P., 1937.

Schwarz, F. A. O. (jr.): Nigeria: The Tribe, the Nation, or the Race. M.I.T. Press, 1965.

Seligman, C. G.: Races of Africa. O.U.P., 1959.

Temple, C. L.: Native Races and their Rulers. Argus, 1928 
Artikels uit die volgende tydskrifte:

Afrika-Instituut Bulletin (verskeie).

Internationale Spectator (Afrika-nummer), Mei 1967.

Keesings, Jun. 1967.

News Check (verskeie).

Newsweek, Jul. 1967.

Optima, Des. 1966.

Time, Jul. 14, 1967. 